\title{
Qualifying for a Type of Pension and Poverty Measurement
}

\author{
Andrews Doeh Agblobi \\ Department of Banking \& Finance, University of Professional Studies, Accra, Ghana \\ Email address: \\ a_agblobi@yahoo.com \\ To cite this article: \\ Andrews Doeh Agblobi. Qualifying for a Type of Pension and Poverty Measurement. International Journal of Economic Behavior and \\ Organization. Vol. 9, No. 1, 2021, pp. 10-18. doi: 10.11648/j.ijebo.20210901.12
}

Received: December 19, 2020; Accepted: January 4, 2021; Published: January 12, 2021

\begin{abstract}
The period of exiting from once full-time years of daily employment to a period of less time constraint can be a period of excitement or misery in poverty. It is pathetic that at one period, an individual is on a payroll of an employer but at another period the individual is not on any pension roll. The objective of the paper is to examine the qualification criteria for a pension and the effect of a pension type on poverty. Primary data was gathered from residences with at least one person aged 60 years old or older across 24 sampled localities in the country. A logistic regression estimation method was employed for the data analyses. The findings of the study indicate that different pension systems have different qualifying criteria that the individual must satisfy to be able to get the monthly pension. The conceptual framework indicates that although some individuals contributed to the SSNIT pension scheme, they could not qualify for the monthly pension due to the inability to satisfied the minimum number of months. The findings also show that the SSNIT pension recipients household were less likely of being poor compared to the CAP30 pensioners. It is recommended that SSNIT should embark on vigorous awareness creation exercise to educate the general public about the tenets of social security pension.
\end{abstract}

Keywords: Pension Type, Ssnit Pension, Absolute Poverty, Age, Qualification, Retirement

\section{Introduction}

The qualification for a social security pension in most countries is not automatic irrespective of which type of pension system is in place [2]. Several pre-determined criteria are usually expected for an individual to qualify for a defined benefit (DB) social security pension. A typical DB will expect an individual to have met the minimum length of service, be of a certain age, spend certain number of years in the country, level of income bracket, and whether contributed or not to be satisfied [11]. Thus, the receipt of pension is not automatic even if it is a universal old-age pension.

In a country such as South Africa that has both noncontributory and contributory pension systems, even the noncontributory is subject to a mean-test that is some form of qualification criteria [17]. In other countries such as the United Kingdom, United States of America, and Malaysia, one must be a citizen and be of a certain age bracket and must contribute for a minimum period to be able to qualify for social security pension. For instance, in the United Kingdom, a person must be at least 55 years, in the United States of America a minimum of 62 years and in Malaysia at least 55 years [16].
Age is not the only criterion for qualifying for pension anyway. Similar to other countries, Nigeria and Ghana also have both contributory and non-contributory pension systems. In Ghana, there are different qualifying conditions for each pension system [2]. Qualification is the process of satisfying a predetermined requirement to access a pension benefit. The problem is many contributors to a pension scheme do not know these technicalities and are usually confronted with them only at the time of retirement. The policymaker also has not taken the pain to evaluate the implications of such qualifications in relation to poverty alleviation.

The objective of this paper is to examine the qualification criteria for social security pension and investigate the effect of a pension type on poverty in Ghana. Few studies exist on pension and poverty in Ghana but very limited studies exist concerning the examination of qualifying criteria for a pension and a pension type effect on absolute poverty. For example, previous studies on the role of pension on poverty and a Review of Public Pension Schemes: Perspective of Social Protection Floor Framework but had no or limited analyses on pension type [21, 1]. Another study on source of retirement income among formal sector workers also had nothing on the type of pension and its impact on poverty [23]. 
The conceptual framework contributes to the literature as it links the pension system in the country to how an individual can qualify for old-age pension. The framework illustrates the various circustances under which an individual can be placed on, that is as an employee, self-employed or unemployed that can affect the individual inability to get a pension. The novelty of the framework is it shows from the onset how to tackle oldage poverty by having policies to deal with those who are potentially going to be outside pension benefits. The paper also serves as a source of reference for further research in qualification for a pension and poverty as the first scholarly study with this focus. Finally, this paper contributes by informing the working population on how to qualify for a pension to avoid old-age poverty.

The rest of the paper is structured such that section two examines a conceptual framework for pension tree and section three discusses the measurement of the type of poverty. Section four explains the empirical model specification and type of data and section five presents the results. The sixth section discusses the conclusion and policy implications.

\section{Conceptual Framework of Receipt of Old-age Pension}

The SSNIT pension scheme requires an individual to purchase annuities (or contribute $5.5 \%$ of the basic salary) while the employer also contributes $13 \%$ in the periods before retirement to qualify for social security pension in the country. Overall, expenditures of employers in Ghana do include social security tax for their workers as the contribution to their retirement is mandatory for formal sector workers.

Aside, the contributory SSNIT pension, another type of pension scheme, CAP 30 (i.e. Government pension) exist as non-contributory government transfer scheme [1]. The government pension is solely financed by the taxpayer and the beneficiaries do not make contributions to access the benefits. Several workers of the public sector and the Security Services are covered under the CAP30 pension scheme. See Figure 1 the conceptual framework of pension benefit tree and its linkages of receipt of pension to past behaviour.

The conceptual framework of 'pension benefit tree' shows a backward decision trail of how the past behaviour of the elderly affects their likelihood to get old-age pension irrespective of which country they reside in. In this model, the old-age pension is equivalent to income replacement for older persons to avoid poverty [24, 9]. The life-cycle hypothesis theory predicts that a representative individual will smooth consumption over the lifetime to avoid old-age poverty (famine) [3]. This the individual will do by purchasing insurance which is expected to kick-start when the individual retires at old age [20]. In period one which is before age 60, for example in Ghana, the individual who is employed in the formal sector contributes together with the employer on a monthly percentage of salary to the pension provider, SSNIT. The employer is under compulsion to deduct and remit to SSNIT. Other categories of formal sector employment workers are those on Government pension or CAP30. For this group, the employer does not deduct from their salary neither does the employer sets aside funds for their pension payment. For the self-employed worker, they must deduct and send $13.5 \%$ to SSNIT and $5 \%$ to the occupational pension scheme provider of their choice. The period two in the conceptual framework is when the individual gets the benefit of the decision made while in employment in period one (see Figure 1).

In a developing country such as Ghana, very few individuals become employees while the vast majority are self-employed and others unemployed. Usually, the individuals that constitute employees do work in the formal sector, whereas the selfemployed mostly work in the informal sector of the economy. The individuals who work as employees or self-employed can make contributions over a given minimum qualifying years to get an old-age pension, as shown in (A) and (C) of Figure 1. To qualify for a pension in the country, it depends on the type of pension system one is on. For the contributory SSNIT pension, the individual must contribute for a minimum period of 180 months. However, for the non-contributory CAP30 pension, the individual must be an employee of Government and also be fortunate to have legislation that indicates that the individual shall access pension benefit directly from the government pension. A qualifying year for the Government pension is a minimum period of ten years of unblemish record of service. Whereas CAP 30 beneficiaries who do not contribute gets old-age pension as in (C), another set of individuals who might have contributed but do not satisfied the qualifying years to get a pension get a lump-sum as in (B) and (D). The concern with the category of workers on CAP30 who do not contribute but get an old-age pension in $(\mathrm{C})$, is whether the lack of such individuals to contribute and be rewarded with a pension, undermines the economic principles of trade-offs? The rest of the individuals who did worked but did not make contributions (as short-term contract staffs) or were unemployed and could not make contribution do not get a pension as shown in (E), and $(\mathrm{F})$. These categories of individuals who do not get a pension at old age may be exposed to poverty $[3,19]$.

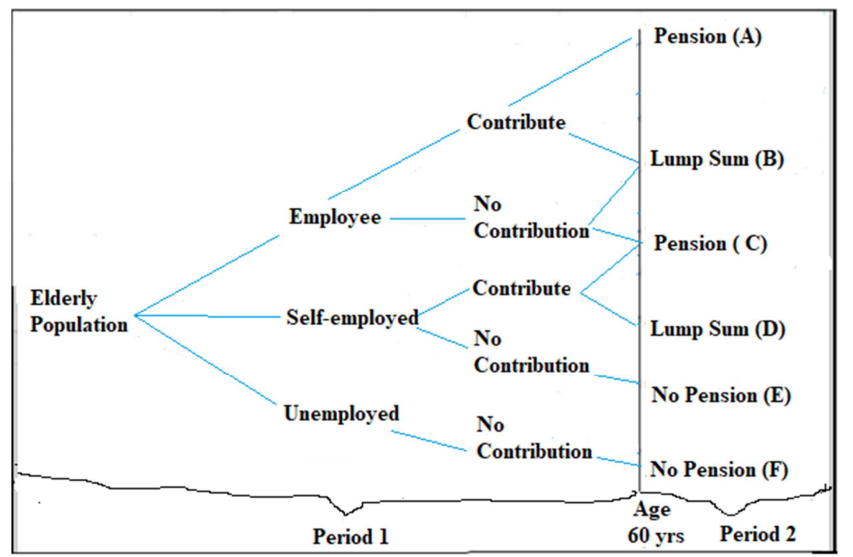

Source: Author's construct.

Figure 1. Conceptual framework of pension benefit tree: linkages of receipt of pension to behaviour. 


\section{Measurements of Types of Poverty}

The widely used measure of poverty index proposed by [12] was adopted in various ways to measure absolute poverty, depth and severity similar to other studies such as $[15,14,10,18]$. These three measures are adequate to capture various aspects of poverty and vulnerability that confronts the elderly as a subgroup within the entire population [18]. The choice of a certain definition of poverty is based on the availability of data [6]. A choice was made to use households' consumption expenditure similar to original data used by [12]. The author's [12] model of measuring expenditure absolute poverty is as follow (1):

$$
P_{\alpha}=\frac{1}{n} \sum_{i=1}^{q}\left(\frac{y_{p}-y_{i}}{y_{p}}\right)^{\alpha}
$$

where $\alpha$ is the parameter of the degree of inequality aversion or the weight assigned to the problem of poverty reflecting the weight placed on the welfare levels of the poorest among the poor which ranges between $0 \leq \alpha \leq \infty$; $q$ is the number of the particular population defined to be poor; $y_{p}$ is the estimated poverty line in various years; $y_{i}$ is the expenditure of a household below the poverty line; $i=1,2,3, \ldots$, qth individual households and $n$ is the size of target population's expenditure or the number of the sample individual households. The (1) estimates the percentage of individual households within a population of interest that are referred to as poor. This usually referred to as the headcount poverty or the absolute poverty and the poverty gap relates to its intensity [13]. The special case of $\alpha$ can vary between 0 and 2 to signify other types of poverty measures. For instance, where the $\alpha=0$, the index measures the expenditure of the poor as the proportion of the target population formally written as follow (2):

$$
P_{0}=\frac{q}{n}
$$

Most studies use headcount methods in measuring expenditure poverty status (GSS, 2014; Faye, 2007). The (1) and (2) ranked individuals from the poorest $(i=1)$ to the richest $(i=n)$. To take account of the depth (gap) of poverty, $\alpha=1$ is used and the model is re-written as:

$$
P_{1}=\left(\frac{q}{n}\right)\left(\frac{y_{p}-\mu_{p}}{y_{p}}\right)
$$

where $\mu_{p}$ is the mean expenditure of the poor. Now, where the $\alpha=2$ or $P_{2}$ index (square of poverty gap) accounts for the distribution among the poor and not poverty incidence or depth measured in equation (1) to (3). The authors [12] model was decomposed in the existing literature to assess the effect of changes in a subgroup on the larger national population poverty. The $[14,13,17]$ have used similar models where the population was divided into $m$ subgroups. Thus, to obtain the effect of the subgroups poverty on the whole population, the subgroup population shared weights are summed up as $\left(P_{\alpha j}\right.$, where $\left.j=1, \ldots m\right)$ :

$$
P_{\alpha}=\sum_{i=1}^{m} x j P_{\alpha, j}
$$

where $x j$ is the population share of the $j$ th group and $P_{\alpha, j}$ is the poverty level in the $j$ th group. The (4) implies that national poverty is the weighted average of the poverty incidence of the various subgroups with weighted proportional population share [14]. An increase in poverty in a subgroup $j$ th would increase national poverty at a rate given by the population share or contribution $[12,14]$ of subgroup $j$ as:

$$
\lambda_{j}=\frac{x j P_{\alpha, j}}{P_{\alpha}}
$$

where $\lambda_{j}$ is the contribution of group $j$ to national poverty. In this study, (5) constitutes the model for the analysis of the poverty status of households with elderly.

\section{Type of Data and Empirical Model Specification}

The study employed a randomly sampled field survey data with various household settings with elderly persons and investigated their likelihood of being poor. The data was obtained directly as a field study from a household with elderly that was randomly determined through a formula. The study conducted a face to face interview in households with elderly from 24 localities across three regions in the country. The type of data collected centred on general demographic information about the gender, age, marital status, household size, education and employment type. The other type of data collected was on income, pensions, and expenditure of the sample. The questions about these variables bordered on amount of income, amount of pension, type of pension, and households' expenditure. The model as specified in (6) used poverty as the dependent variable and predicts that household poverty could be reduced through receipt of a type of pension benefit. The empirical model is specified as follows (6):

$$
\begin{aligned}
\log \left(\frac{p}{1-p}\right)= & \alpha+\beta_{1}\left(D_{P T Y E}\right)_{i}+\beta_{2}\left(D_{E P}\right)_{i}+\beta_{3}\left(D_{E C}\right)_{i}+\beta_{4}\left(D_{W E}\right)_{i}+\beta_{5}\left(D_{R A}\right)_{i} \\
& +\beta_{6}\left(D_{A G E 2}\right)_{i}+\beta_{7}\left(D_{A G E 3}\right)_{i}+\beta_{8}\left(D_{P R I}\right)_{i}+\beta_{9}\left(D_{M J S S}\right)_{i}+\beta_{10}\left(D_{S E C}\right)_{i} \\
& +\beta_{11}\left(D_{P S E C}\right)_{i}+\beta_{12}\left(D_{H D}\right)_{i}+\beta_{13}\left(D_{G E N}\right)_{i}+\beta_{14} R E M I_{i}+e_{i}
\end{aligned}
$$


where $D$ is a dummy, $\left(\frac{p}{1-p}\right)$ is the odds ratio and $p$ is a probability of being poor as the numerator and $(1-p)$ is the probability of non-poor as the denominator. See table 1 for the definition of the variables. It suggests that a particular type of pension recipient will be more or less likely to be poor if the sign of the coefficient is positive or negative and about $x_{i}$ times compare to the other, all others things being equal. The $e_{i}$ represents the error term at 5 per cent.

Table 1. Variables definitions and interpretation of estimated coefficients.

\begin{tabular}{|c|c|c|c|}
\hline Variable & Definition & Measurement & $\begin{array}{l}\text { Expected } \\
\text { sign }\end{array}$ \\
\hline$D_{E P}$ & Elderly persons only households & A dummy variable that equals 1 for household with only elderly and 0 otherwise. & + or - \\
\hline$D_{E C}$ & Elderly and children households & A dummy variable that equals 1 for household with elderly and children and 0 otherwise. & + or - \\
\hline$D_{W E}$ & Working age and elderly & A dummy variable that equals 1 for working age and elderly and 0 otherwise. & + or - \\
\hline$D_{R A}$ & Rural locality & A dummy variable that equals 1 for household in rural areas and 0 otherwise. & + or - \\
\hline$D_{A G E 2}$ & Age (Old) & A dummy variable that equals 1 for household with elderly age 'old' and 0 otherwise. & + or - \\
\hline$D_{P R I}$ & Primary & $\begin{array}{l}\text { A dummy variable that equals } 1 \text { for household with elderly up to primary education and } 0 \\
\text { otherwise. }\end{array}$ & - \\
\hline$D_{M J S S}$ & Middle school/JSS & $\begin{array}{l}\text { A dummy variable that equals } 1 \text { for household with elderly up to middle school/JSS education } \\
\text { and } 0 \text { otherwise. }\end{array}$ & - \\
\hline$D_{S E C}$ & Secondary & $\begin{array}{l}\text { A dummy variable that equals } 1 \text { for household with elderly up to secondary education and } 0 \\
\text { otherwise. }\end{array}$ & - \\
\hline$D_{P S E C}$ & Postsecondary & $\begin{array}{l}\text { A dummy variable that equals } 1 \text { for household with elderly up to postgraduate education and } 0 \\
\text { otherwise. }\end{array}$ & - \\
\hline$D_{G E N}$ & Gender & A dummy variable that equals 1 for household with male elderly and 0 otherwise. & + or - \\
\hline$R E M I_{i}$ & Remittance & Remittance amount to households with elderly. & + or - \\
\hline Pty & Pension Type & A dummy variable that equals 1 for household with SSNIT pension and 0 otherwise. & - \\
\hline
\end{tabular}

Source: Author's construct.

\section{Empirical Results}

\subsection{Socio-demographic Characteristics of Households with Elderly}

Table 2 highlights the socio-demography characteristics of the respondents in terms of gender, age group, marital status, household head and educational attainment. The higher number of males compared to females is explained through the selection of pensioners and non-pensioners. Out of the 75 elderly recipients of pension benefits, only 11 (or 14 per cent) were females. Most of the pensioners were males who worked and retired from formal sector employment. The number of respondents reduces as the age increases which was expected. However, the average age of 73.6 years old indicated that many of the elderly in the sampled localities were living longer compare to 64.17 years' life expectancy for Ghana in 2020. Approximately, 50 per cent of the elderly were still married while 43.1 per cent were widow or widower. The high percentage of the widow or widower could be expected considering the average age of 73.6 years old. Close to 70 per cent of the elderly claimed that they were household heads and approximately 66 per cent indicated that they take care of their grandchildren. This should be interpreted carefully because when compared to the total population it could be lower. The household size of six persons and the 66 per cent of elderly still taking care of the grandchildren supports the claim that any extension of financial assistance to the elderly goes to help their grandchildren [18]. The average household size also confirms $[19,7]$ assertion that the elderly rarely live alone in developing countries. The 24 per cent of the elderly live in households where a working person (age 15 - 59) was the household head described as cohabitation.

Close to about half of the elderly persons live in mixed households $(0-14 ; 15-59$ and $60+)$ composed of three or four generations ( 46.4 per cent). This is consistent with the findings of [22] that most elderly live in an intergenerational household and uses cohabitation as a social protection mechanism. An estimate of 19 per cent of elderly persons lives alone or with another person of the same generation as elderly only households. An estimate of 22.6 per cent of elderly persons lives with other person's age between 15-59 years referred to as working age. An estimate of 12 per cent of elderly persons was living in households with children only $(0-14)$.

Over 60 per cent of the elderly have either never been to school or could not read and write informal English language. As the educational status increases, the number of elderly who attended these institutions decreases in pursuit of formal education. This is similar to the national estimates obtained by GSS with the GLSS 6 report at the national level. The highest pension recipient elderly was aged 96 years while the nonpension recipient was aged 116 years old. The oldest pensioner respondent was a CAP30 recipient who retired as Military officer in 1974. The highest SSNIT pension recipient was a 90-year-old who retired as a public Health Sector worker. The 
age of pension recipients and non-recipients indicated that the pension system in the country was still fairly young. Approximately 23 per cent of the randomly sampled elderly in the study localities were pension recipients. The non-pension recipients' elderly constitute the largest proportion of the random sample households with elderly.

Table 2. Socio-demography characteristics of households with elderly.

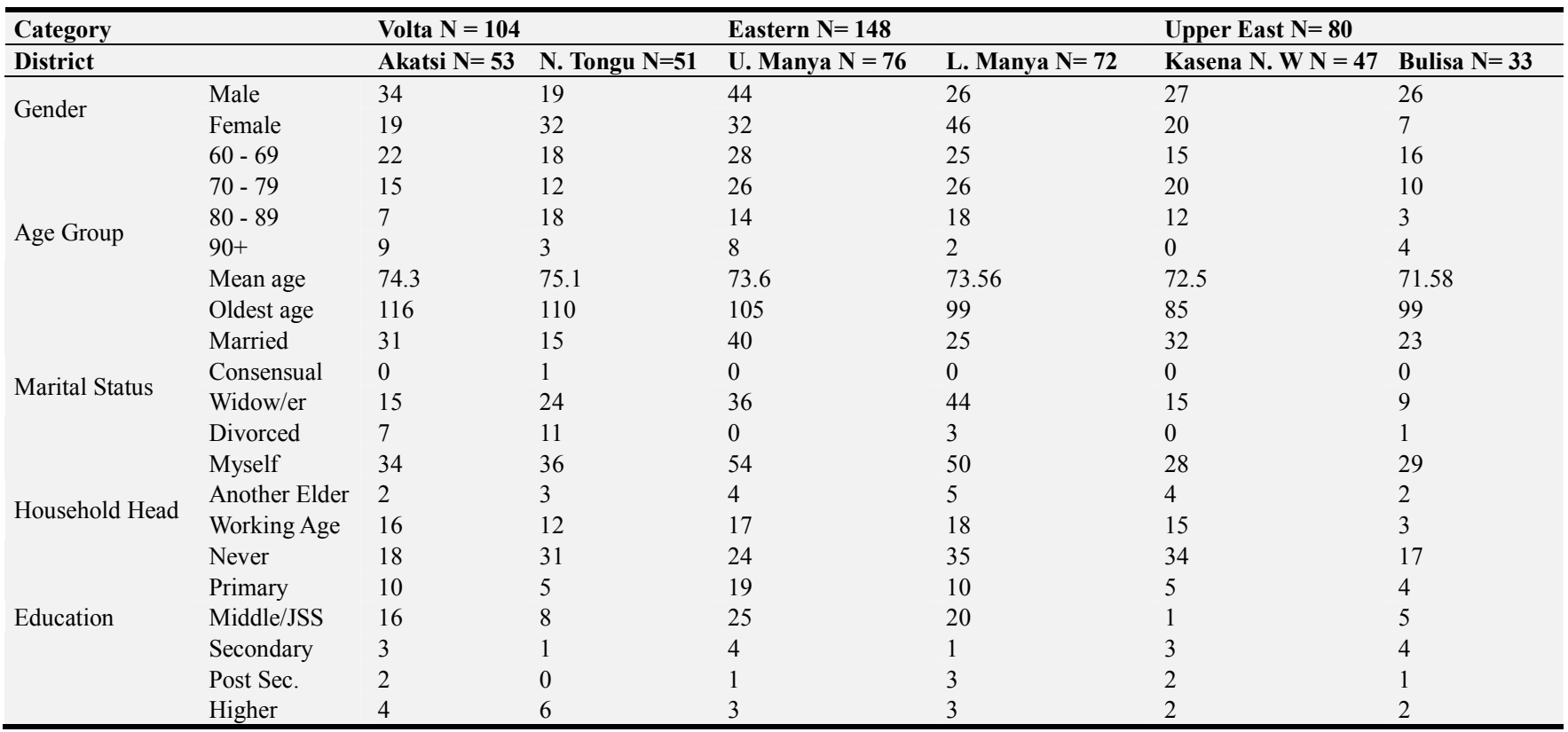

Table 2. Continued.

\begin{tabular}{|c|c|c|c|c|}
\hline Category & & Total $\mathbf{N}=332$ & Total (\%) & National (\%) \\
\hline District & & $U=147 R=185$ & 44.755 .3 & 45.854 .2 \\
\hline \multirow{2}{*}{ Gender } & Male & 176 & 53 & 44.2 \\
\hline & Female & 156 & 47 & 55.8 \\
\hline \multirow{5}{*}{ Age Group } & $60-69$ & 124 & 37.3 & 46.9 \\
\hline & $70-79$ & 109 & 32.8 & 33.9 \\
\hline & $80-89$ & 61 & 18.4 & 19.2 \\
\hline & $90+$ & 26 & 7.8 & 8.4 \\
\hline & Oldest age & & & \\
\hline \multirow{5}{*}{ Marital Status } & Married & 166 & 50 & 51.9 \\
\hline & Consensual & 1 & 0 & 1.8 \\
\hline & Widow/er & 143 & 43 & 31.4 \\
\hline & Divorced & 22 & 6.6 & 8.7 \\
\hline & Myself & 231 & 69.6 & \\
\hline Household Head & Another Elder & 20 & 6 & \\
\hline \multirow{6}{*}{ Education } & Never & 159 & 47.9 & 60.4 \\
\hline & Primary & 52 & 15.7 & 8.6 \\
\hline & Middle/JSS & 75 & 22.6 & 20.5 \\
\hline & Secondary & 16 & 4.8 & 3.4 \\
\hline & Post Sec. & 9 & 2.7 & 5.6 \\
\hline & Higher & 20 & 6 & 1.5 \\
\hline
\end{tabular}

Source: Author's estimates

\subsection{Number of Elderly Engaged in Employment Activities}

Table 3 summaries the employment activities that the elderly persons were engaged after the retirement age. Approximately, 54 per cent of the respondents were engaged in some form of employment activities. The type of employment activities they were engaged in were mainly informal sector. Thus, approximately, 90 per cent of the elderly were either working as self-employed persons in agriculture (68.5 per cent) or self-employed persons in nonagriculture activities (i.e. 20.8 per cent). Those engaged in the agricultural activities were involved in the rearing of livestock especially in the Kasina Nakana and Bulsa Districts; while those who were growing food crops and other agriculture produce were in Akatsi and North Tongu Districts as well as Lower and Upper Manya Districts.

The elderly who were engaged in the farming activities did indicate that they took it as their full-time jobs. Among those 
who claimed to be working, about 25.3 per cent of them indicate they were working on the part-time bases. Those who were working on part-time bases were some of the elderly who were working in the private or public formal sector jobs. The main reason cited by the elderly for working was to earn an additional income.

Table 3. Number of elderly engaged in employment activities after retirement.

\begin{tabular}{|c|c|c|c|}
\hline & & Frequency & Per cent \\
\hline \multicolumn{4}{|c|}{ Number of elderly that have a job } \\
\hline & Yes & 178 & 53.6 \\
\hline & No & 154 & 46.4 \\
\hline Total & & 332 & 100 \\
\hline \multicolumn{4}{|c|}{ Types of jobs } \\
\hline & Formal (public/Gov't.) & 4 & 2.2 \\
\hline & Formal (private) org. & 15 & 8.4 \\
\hline & Informal (Self-employed agric) & 122 & 68.5 \\
\hline Total & & 178 & 100 \\
\hline \multicolumn{4}{|c|}{ Full-time or part-time jobs } \\
\hline & Full -time & 133 & 74.7 \\
\hline & Part-time & 45 & 25.3 \\
\hline Total & & 178 & 100 \\
\hline
\end{tabular}

Source: Authors' estimates.

\subsection{Number of Elderly on Pension}

The findings in table 4 show that approximately 82 per cent of the respondents did not contribute to the mandatory social security scheme during their active working life. Thus, a large proportion of the elderly was unable to utilise the financial system to prepare for their life in old age. In table 4, out of the 75 elderly persons that receive a pension, only 42 persons who contributed to the SSNIT scheme became pensioners. This finding confirms the claim that the long-standing economic debate as to whether the data supports the prediction that people save voluntarily when they were young and run down their assets when they are old may depend on whether they were forced or allowed to voluntarily contribute [7]. Many of the households with elderly sampled did not purchase annuity hence the lack of pension benefit at retirement. Most of them might have worked in the informal sector of the economy. The rest of the pensioners, mostly CAP30 pension which includes Ghana Armed Forces (GAF) pension recipients did not contribute because it is a non-contributory scheme. It is not clear whether the inability of recipients of CAP30 pension to contribute to a pension scheme could be termed as a lack of preparing or purchasing annuities towards retirement.

Also, the finding shows that it is not everyone who contributed to the social security scheme that qualified for the monthly pension benefits. This could be seen from the 59 persons (or 17.8 per cent) that ever-made contributions to the social security scheme. Of the 59 elderly persons, 42 persons were receiving social security pension benefits at retirement while the rest of 17 (or 29 per cent) persons did not get a pension. The data supports the conceptual framework on pension benefit tree developed in Figure 1 where those who contribute but did not qualify gets lump sum. Besides, a large number of non-pension recipients did not contribute to the public pension scheme. The result confirms the proposition that in making choices, many people do not purchase insurance annuities voluntarily to maximise their lifetime utility [4]. Thus, individuals fail to make a rational choice due to procrastination, short-term gratification and lack of understanding of diversification or investment [4].

Table 4. Number of elderly on pension.

\begin{tabular}{lll}
\hline Pension access and contributions made & Frequency & Percent (\%) \\
\hline Pension récipients & 75 & 22.59 \\
Non-pension récipients & 257 & 77.4 \\
Total & 332 & $100 \%$ \\
Pension recipients & & 56 \\
SSNIT & 42 & 44 \\
CAP30 & 33 & $100 \%$ \\
Total & 75 & 17.77 \\
Contributed to SSNIT & 59 & 82.2 \\
Yes & 273 & $100 \%$ \\
No & 332 & 71.2 \\
Total & & 28.8 \\
Contributed and receives a pension & 42 & $100 \%$ \\
Yes & 17 & 59 \\
No & 59 & \\
Total & & \\
\hline
\end{tabular}

Source: Author's estimates. 
Therefore, based on the findings of the study, high rate of poverty exists among the elderly in the studied localities and it was about twice higher than the national absolute poverty. The inability of many of the elderly to purchase annuities to get social security pension affirms the predictions of the life cycle hypothesis that they would be poor. Thus, the finding is consistent with [3,5] who found that household without annuities had slightly negative wealth in their old age. It is also supported that households headed by elderly do have a higher poverty rate of approximately 50 per cent than the national average in Ghana [18].

\subsection{Calculation of Different Types of Household Poverty}

Table 5 reports the authors' estimate of poverty on pension recipient or not, location and gender of the elderly persons in the household. Foster, Greer and Thorbecke framework, especially equations (1) to (5) were used to estimate different types of poverty as shown in table 5 . In table 5, the estimated headcount poverty for pension recipients was 9.3 per cent compared to non-pension recipients that were 53.3 per cent. These figures indicate that compared to non-pension recipients, there was lesser number of households with pension recipients below the poverty line. Thus, at old age, the standard of living among households with pension recipients is higher. Similarly, the estimated poverty gap index for pension recipients was 3.8 per cent compared to 21.26 per cent for non-pension recipients. This shows the extent to which households are below the poverty line. In other words, how much would a policymaker need to support the household's expenditure on average to bring them closer or above the poverty line? The finding means that the policymaker would need to spend far more to address households with non-pension recipients' poverty challenge compared to pension recipients. The overall estimate of poverty among household with elderly was 43.8 per cent.

Now, among the major types of pension, the SSNIT pension recipients had a lower poverty rate of 4.65 per cent compared to CAP30 recipients that had 18.75 per cent. The finding shows that there is far fewer number of households with SSNIT pension recipients below the poverty line compared to CAP30 recipients.

As at the time of the study, the minimum monthly pension benefits under the SSNIT pension was GHc 246.00 (or GHc $2,952.00$ per annum in 2016). In comparison, such an amount was about twice higher than the national poverty line of GHc 1,314.00 per annum. Poverty among the entire sample concerning the location such as urban vs. rural, and male vs. female can be seen in the bottom part of table 5 .

Table 5. Calculation of different types of household poverty.

\begin{tabular}{llll}
\hline Items & HeadCount Poverty (\%) & Poverty Gap Index (\%) & Square Poverty Gap Index (\%) \\
\hline Pension recipient & 9.3 & 3.8 & 1.16 \\
Non-Pension recipient & 53.3 & 21.26 & 8.48 \\
SSNIT Pension & 4.65 & 1.16 & 0.29 \\
CAP 30 pension & 18.75 & 10.48 & 5.86 \\
Urban & 31.2 & 8.14 & 2.1 \\
Rural & 52.97 & 24.63 & 11.45 \\
Male & 33.5 & 13.7 & 5.6 \\
Female & 55.13 & 22 & 8.81 \\
\hline
\end{tabular}

Source: Author's estimates.

\subsection{Effect of Pension Type on Poverty}

Table 6 presents the results obtained from the regression estimates of the effect of pension type on absolute poverty. In table 6 , the findings shows that the probability of recipient of a SSNIT pension being poor was 0.116 times less likely compared to a recipient of Government pension or CAP 30. Thus, it is less likely for a household with SSNIT pension recipient to be poor compared to other types of pension schemes. The main reason that account for this was because the SSNIT pension is the widest pension coverage of beneficiaries in the country and also have a cut-off for a minimum pension below which anyone whose pension is lower than it will be automatically placed above the minimum pension instead. At the time of this study, even the minimum pension is higher than the monthly daily minimum wage in the country. The SSNIT pension also uses yearly indexation tools to adjust the pension benefits at the beginning of each year. On the whole, once an elderly was a pensioner, the household was less likely to be poor. The monthly pension benefits paid to the recipients were based on their basic salary.

The calculation of the pension benefit is based on a predetermined formula of the percentage of three best years' average basic salaries. The issue is if there should be a reform such that the annuities purchased is based on the gross monthly salary and the social security pension computations are based on the gross salary, it should further lower the poverty level. Similar to the findings of [8] the result confirms the position that a better pension income for retirees would lead to more sustainable consumption and would lower overall poverty level. The results are statistically significant. 
Table 6. Effects of pension type on poverty.

\begin{tabular}{lllll}
\hline Independent variable & Coefficient & Standard error & Odds ratio & P-values \\
\hline Constant & 23.978 & 8006.29 & 25906940359 & 0.998 \\
SSNIT & -2.155 & 0.826 & 0.116 & 0.009 \\
Elderly persons only & 2.546 & 0.437 & 14.1 & 0.000 \\
Elderly \& Children & 2.419 & 0.503 & 11.231 & 0.000 \\
Elderly \& Working Age & 1.019 & 0.348 & 2.77 & 0.003 \\
Age old & 0.042 & 0.365 & 1.043 & 0.909 \\
Oldest old age & -0.137 & 0.403 & 0.872 & 0.734 \\
Primary & -0.254 & 0.403 & 0.776 & 0.528 \\
Middle School \& JSS & -1.294 & 0.408 & 0.274 & 0.002 \\
Secondary & -2.233 & 0.82 & 0.097 & 0.005 \\
Post-Secondary & -1.962 & 1.225 & 0.141 & 0.109 \\
Higher \& degree & -20.992 & 8006.296 & 0.000 & 0.998 \\
Urban & -1.008 & 0.315 & 0.334 & 0.000 \\
Gender & -0.092 & 0.31 & 0.912 & 0.767 \\
Remittance & 0.134 & 0.322 & 1.143 & 0.678 \\
\hline
\end{tabular}

Source: Author's estimates.

Estimation method: ML. Logit. Dependent variable = Poverty rate. No. Obs. 332; Overall percentage predicted is $74.9 \%$.

\section{Conclusions}

The objective of the paper is to examine the qualification for pension and the effect of pension type on poverty in Ghana. The investigation of the objective was in two parts. The first part was about the examination of the qualification for a pension that was undertaken with the construction of a conceptual framework to analyse a two-period model. The finding from the conceptual framework shows that some category of contributors to the SSNIT pension may not qualify for a pension simply because they did not meet the minimum period of contributions. The second part of the objective was about which type of pension have the highest impact on poverty. In addressing this part of the objective, the paper estimated three different types of poverty using the field data obtained. The calculations with [12] model shows that a household with elderly as a pension recipient have a low poverty rate of 9.3 per cent compare to $53 \%$ for those with elderly that do not get a pension. The empirical results through the regressions analyses also show that household with elderly that receives SSNIT pension was less likely to be poor by 0.116 times.

In terms of the findings from the conceptual framework which was also confirmed by the data, about 17 (or 29\%) of those contributed to SSNIT pension do not get a pension. This category of contributors could eventually fall below the poverty line.

Following these findings, the government should institute a social programme to assist those categories of contributors who might have contributed at least $2 / 3^{\text {rd }}$ and over but do not satisfy the minimum period of 180 months to get a minimum pension. Thus, the policymaker should be able to project how many persons among a particular age group will be unable to qualify for a pension and initiate policies to address such occurrence. This will help alleviate old-age poverty. Additionally, the managers of the SSNIT pension should embark on education activities to sensitise all Ghanaians about how the pension system functions.

\section{Limitation}

The study analyses the two major types of public pension systems, SSNIT and Government pension or CAP30, although Ghana Universities Staffs Superannuation Scheme also exist. The selection was based on availability of data.

\section{References}

[1] Agblobi, Andrews Doeh and Osei-Fosu, Anthony Kofi (2017). A Review of Public Pension Schemes: Perspective of Social Protection Floor Framework. International Journal of Humanities and Social Science. Vol. 7(6), p. 134-145.

[2] Anku-Tsede, Olivia; Amertowo, Aaron and Amankwa, Albert (2015). Managing Pension Funds in Ghana: Overview. Business and Management Research. Vol.4 (1), p. 25-33.

[3] Balco, M., Sebo, J., Mestan, M., \& Sebova, L. (2018). Application of the Lifecycle Theory in Slovak Pension Syetem. Ekonomicky casopis. Vol. 66 (1), p .64-80.

[4] Barr, N., \& Diamond, P. (2009). Reforming pensions: Principles, analytical errors and policy directions. International Social Security Review. Vol. 62 (2), p. 5-29.

[5] Bruce, N., \& Turnovsky, S. J. (2013). Social security, growth, and welfare in overlapping generations economies with or without annuities. Journal of Public Economics. Vol. 101 (1), p. 12-24.

[6] Dartano, T. (2011). Does Choice between an Endogenous and a Fixed Poverty Line Affect the Poverty Outcome of Policy Reform? Modern Economy, Vol. 2 (1), p. 667-673.

[7] Deaton, A. (2005). Franco Modigliani and Life Cycle Theory of Consumption. Convegno Internationale Franco Modigliani, Academia Nazionale dei Lincci. Rome. 
[8] De la Torre Torres, O. V., Figueroa, E. G., \& Alvarez-Garcia, J. (2017). The Cost of homogeneity in life cycle pension funds: An explanation demand's inelasticity of Mexican pension funds with a performance attribution test. Eurepoan Research on Management and Business Economics. Vol. 22 (3), p. 117-126.

[9] Dethier, J.-J., Pestieau, P., \& Ali, R. (2011). The impact of a minimum pension on old age poverty and its budgetary cost. Evidence from Latin America. Revista de Economia del Rosario. Vol. 14 (2), p. 135-163.

[10] Dercon, S., \& Shapiro, J. (2007). Moving On, Staying Behind, Getting Lost: Lessons on Poverty Mobility from Longitudinal Data. In D. a. Narayan, Moving out of Poverty. CrossDisciplnary Perspective on Mobility. (pp. 77 - 126). USA: Palgrave Macmillan and the World Bank.

[11] Feher, Csaba and de Bidegain, Ignatius (2020). Pension Schemes in the COVID-19 Crisis: Impact and Policy Considerations. IMF. Fiscal Affairs. Website: enspecial-serieson-covid19pension-schemes-in-the-covid19-crisis-impactsand-policy-considerations.pdf

[12] Foster, J., Greer, J., \& Thorbecke, E. (1984). A Class of Decomposale Poverty Measure. Econometric, Vol. 52 (2), p. 761-766.

[13] Franco, D., Marino, R. M., \& Tommasino, P. (2008). Pension Policy and Poverty in Italy: Recent Development and New Priorities. Giorrale degli Economists Amali di Economia. Vol. 67 (2), p.119 - 159

[14] GSS. (2007). Pattern and Trends of Poverty in Ghana (19912006). Ghana Living Standard Survey Round 5 (GLSS5). Accra: Ghana Statistcal Service.

[15] GSS. (2014). Poverty Profile in Ghana (2005 - 2013). Ghana Living Standard Survey Round 6 (GLSS6). Accra: Ghana Statistical Service.

[16] Janor, Hawati; Yakob, Rubayah; Hashim Noor Azuan; Zanariah; Wel, Che Aniza Che (2016). Financial literacy and investment decisions in Malaysia and United Kingdom: A comparative analysis. Malaysian Journal of Society and Space. Vol. 12 (2), p. 106-118.

[17] Jouste, Maria and Rattenhuber, Pia (2018). A role for universal pension? Simulating universal pensions in Ecuador, Ghana, Tanzania and South Africa. WIDER Working Paper, No.2018/23, ISBN 978-92-9256-465-0, The United Nations University World Institute for Development Economics Research (UNU-WIDER), Helsinki, http://dx.doi.org/10.35188/UNU-WIDER/2018/465-0

[18] Kakwani, N., \& Subbarao, K. (2005). Ageing and Poverty in Africa: the role of Social Pensions. UNDP International Poverty Centre. WP No. 8. p. 1-41.

[19] Kidd, S., \& Whitehouse, E. (2009). Pensions \& Old Age Poverty. In Chapter 3 Closing the Coverage Gap: Role of Social Pension and Other Retirement Income. p. 41 - 56.

[20] Kiff, John (2020). New Financial Instruments for Managing Longevity Risk. Wharton Pension Research Council Working Paper No. 2020-16. http://dx.doi.org/10.2139/ssrn.3659734

[21] Laryea, Margret Momo; Andoh, Charles and Asuming, Patrick (2019). The Role of Pensions in Poverty Reduction in Ghana. African Journal of Governance and Development. Vol. 8 (1), p. 5-23.

[22] Lyberaki, A., \& Tinios, P. (2005). Poverty and Social Exclusion. A New Approach to an old Issue. In I. B.-S. al. (eds), A Health, Aging and Retirement in Europe. Mannheim Research Institute for the Economics of Ageing.

[23] Quartey, P., Kunawotor, M. E., \& Danquah, M. (2016). Sources of retirement income among formalsector workers in Ghana. African Journal of Economic and Management Studies, Vol. 7 (3), p. 366-378.

[24] Rutaguminwa, Sylivia Karen; Hutter, Inge and Bailey, Ajay (2020). We Never Graduate from Care Giving Roles"; Cultural Schemas for Intergenerational Care Role Among Older Adults in Tanzania. Journal of Cross-Cultural Gerontology. Vol. 35 (1), p. 409-431. 